\title{
Teologie kroniek: Skrifverstaan en die Nuwe Hervorming1 Theology Chronicle: Understanding of Scripture and the "New Reformation”
}

\author{
D J Human \\ (Universiteit van Pretoria)
}

\begin{abstract}
Understanding of Scripture and the "New Reformation"

During the last decade a group of South African theologians have stirred a part of the Afrikaans ecclesiastical community with statements and arguments on several faith issues, including the interpretation of the Bible. Adherents of the movement call themselves the New Reformation ("Nuwe Hervorming"). This theology chronicle is an attempt to touch on some hermeneutical challenges for understanding Scripture. To the Church the Bible is the norm and source of faith. Paradigm shifts have been caused by the Enlightenment and influenced the understanding of Scripture. Historical Criticism, for example, has brought multiple perspectives to the reading of biblical texts. More approaches to biblical understanding originated. For the ordinary Bible reader and believer these approaches sometimes seem to be confusing. This explanation is an attempt to create better understanding for Bible reading in our times. It concludes with a short assessment of the current role the New Reformation movement plays in the hermeneutical debate.
\end{abstract}

\section{INLEIDING}

Vanaf antieke tye wou mense die stem van hulle gode hoor. In die wêreld waarin antieke mense geleef het en waarin hulle baie maal bedreig is, moes die gode hulle beskerm, aan hulle leiding gee of hulle red uit allerlei gevare. Hierdie gode het op baie maniere gepraat en boodskappe gestuur: in ' $\mathrm{n}$ storm, ' $\mathrm{n}$ aardbewing of sterk wind (Van der Toorn 1999:354). Deur visioene, drome of ekstatiese belewenisse het gode soms deur middelgangers met hulle aanbidders kommunikeer. Mesopotamiese baru-priesters het hulle gode se stemme gehoor in die patrone van 'n oopgesnyde dierelewer, in die formasies van voëls in die lug of olie wat op water gegooi is. "n Sigbare en estetiese uitstraling van klank of geur of sig het die manifestasie van "n god se "stem" naby aan die mens se oor gebring. Eers met die ontwikkeling van skrif is gode se boodskappe neergeskryf. In die antieke Nabye Ooste het priesters dit as

Referaat gelewer tydens die predikantekonferensie by die fakulteitsopening aan die Fakulteit Teologie, Universiteit van Pretoria op 5 Februarie 2003. 
magiese toorformules gebruik om aanbidders se vrese te besweer, hulle te bemoedig en ook te waarsku.

Die Bybel word vandag in baie opsigte deur kerke en Bybellesers as ' $\mathrm{n}$ toorboek gebruik. Dit word magies toegepas en uitgelê. Met Bybelse toorformules bedwelm mense mekaar soos Bybelsangomas. Daardeur word sommige se optrede goddelik gesanksioneer en funksioneer Bybeltekste in diens van interpreteerders se eie dogma of ideologie.

Soos in die verlede wil gelowiges vandag graag weet wat hulle moet glo, hoe hulle moet leef en aanbid asook watter besluite hulle moet neem. Hulle wil God hoor praat. Daarom lees hulle Bybeltekste met 'n bepaalde verwagting. Almal wil daaruit verantwoordelike "bybelse, christelike of gelowige standpunte" formuleer. Hierdie soeke na God se waarheid en wat die Bybel oor 'n onderwerp sê, word in ons samelewing duidelik deur die stortvloed debatte rondom, onder andere, evolusie en die ontstaan van die skepping, verdeling van stamselle, kloning, homoseksualiteit, seks voor die huwelik, die vrou in die amp, die maagdelike geboorte, die opstanding, die rol van die historiese Jesus, die verhouding tussen Christus en ander godsdienste, asook hoe mense die Bybel moet lees en interpreteer.

Nêrens in die Kerkgeskiedenis of in die epogge van Bybelinterpretasie het mense die Bybel eenvormig gelees of interpreteer nie. Klaarblyklik het hulle God verskillend gehoor, al lees hulle dieselfde tekste. Miskien lees hulle die Bybel met verskillende brille of verskillende kleure oogklappe. Wie is reg en wie is verkeerd? Almal kan tog nie reg wees nie. Sommige individue, groepe of gesagsinstansies is sekerder van hulle standpunte as ander. Dis speurbaar uit talle antwoorde uit briefkolomme, op debatspodiums, vanaf kerkampte en uit kerkbanke, maar selfs van teoloë.

Probleme rondom Skrifverstaan en die lees van die Bybel is te oorweldigend om kortliks op te noem of selfs te bespreek. Die oormag en omvang van die problematiek roep tot nederigheid en toleransie om die debat sinvol te voer sodat dit die geloof in God stig en rig, en pas by die gesindheid van die gelowige en die Kerk. Ek trek slegs enkele pennestrepe as 'n paar gedagte-stimulante vir die debat.

\section{BYBEL - BRON EN NORM VIR DIE GELOOF}

Die Bybel is ' $\mathrm{n}$ geloofsboek wat gelowiges aan God anker. Dit bestaan uit ' $\mathrm{n}$ biblioteek van wyduiteenlopende boeke uit verskillende tye, omstandighede en lewenskontekste. Binne die Christelike tradisie verskil hierdie biblioteek of lys boeke onderling in verskillende geloofsgemeenskappe. Daarom bestaan daar verskillende christelike kanons. Elke kanon dra vir die gelowiges van daardie spesifieke geloofsgemeenskap 
gesag, omdat hulle gesag daaraan gee. Alhoewel daar oorvleueling plaasvind, gee Protestantse, Rooms Katolieke, Ortodokse en Etiopiese geloofsgemeenskappe dus gesag aan boeke wat ander gemeenskappe nie as normatief erken nie. ' $n$ Kanon is dus ' $n$ versameling geskrifte wat normatiewe funksie ontvang van 'n geloofsgemeenskap as riglyn vir hul kerkleer en lewenswandel. Daar bestaan dus ' $\mathrm{n}$ geloofsband tussen die geloofsgemeenskap, sy normatiewe geskrifte, dit wil sê die Bybel, en God. Op dieselfde manier is die Bybel bron en norm vir die lewenswandel en geloofsleer van die Protestante en Gereformeerde tradisie van die Kerk.

Hierdie gesagsband funksioneer binne of buite "n geloofsgemeenskap ook op ' $n$ individuele vlak. Wanneer ' $n$ individu die normatiewe funksie van ' $n$ boek of boeke in die kanon nie erken nie, gee hy/sy nie gesag aan daardie geskrif(te) nie. In die praktyk gebeur dit wel op " $n$ onbewuste en selfs onuitgesproke vlak, wanneer gelowiges byvoorbeeld die Nuwe Testament alleen as normatief vir hulle redding beskou bo die Ou Testament. Sommige boeke in die Ou Testament word nooit gelees, bestudeer of gepreek nie. Sodoende funksioneer ' $n$ kanon binne die erkende kanon. Daarmee staan die belydenis dat Ou en Nuwe Testament saam die kanon vorm slegs as vroom uitspraak op papier.

Die Bybel is egter ook ' $n$ menslike boek. Dit bevat die geloofsgetuienisse van mense oor die groot skeppings-, reddings en onderhoudingsdade van God in die geskiedenis. Die aanvanklike gods- en geloofservarings is deur mense beleef. In drome, visoene, ekstatiese belewenisse en ander reddingservarings het mense God se hand gevoel of sy stem gehoor. Hierdie ervarings is mondelings oorvertel. Later is dit neergeskryf, versamel en verder oorgelewer. Soms is dit weer herinterpreteer met byvoegings en veranderings aan die oorspronklike teks(te). Oorspronklike betekenisse het dan plek gemaak vir nuwe betekenis. So het geskrifte gegroei. ' $n$ Versameling het later groter versamelings geword (vgl Pentateug, Psalmboek, Deuteronomistiese Geskiedswerk, Kronistiese Geskiedswerk). So word dit duidelik dat tekste nie êrens van ' $n$ hemelse poskantoor na die aarde toe gefaks of ge-epos is nie.

In die proses van oorlewering het hierdie geloofsgetuienisse deur interpretasie en herinterpretasie tot die korpusse van die Wet, Profete, Geskrifte en Nuwe Testament versamelings ontwikkel. Uitsprake, boeke en groter versamelings in die Bybel het dus ontstaan in bepaalde historiese en literêre kontekste. Wanneer ons hierdie ontstaansproses en oorleweringskontekste by die interpretasie van tekste ignoreer, bestaan die gevaar om tekste fundamentalisties en biblisisties te interpreteer. Deur teksgedeeltes konteksloos te lees, maak ons van die Bybel 'n toorboek. 
Om Bybeltekste verantwoordelik te lees, beteken dat sy historiese en breër literêre kontekste ernstig geneem word.

Die plek en funksie wat die Bybel ten opsigte van geloofsake in ons "post-moderne" samelewing inneem, word nie duidelik in die kerk deurdink of debatteer nie. Daaraan sal ons aandag moet gee. Is die Bybel met bepaalde boodskappe direk aan ons (in die 21ste eeu) gerig, soos baie gelowiges veronderstel? Of moet ons met die Bybel as versameling geloofsgetuienisse in gesprek tree ten einde eietydse geloofs-, etiese en samelewingsprobleme van ons eie tyd met die verligting van God se Gees self op te los? Die Bybel praat nie altyd oor die probleme en in die taal van ons tyd nie. Daarom oortuig dit my om Bybeltekste eerder as gesagvolle gespreksgenote te beskou in die geloofsworstelinge van die lewe.

\section{PARADIGMAVERANDERINGE EN DIE HISTORIESE KRI- TIEK}

Deur die eeue van Skrifinterpretasie het daar in sowel die Natuur- as Bybelwetenskappe verskillende paradigmaveranderinge plaasgevind (Spangenberg 1998:6-28; 2002:99). Vir ons is die opkoms van die Historiese kritiek in die $18 \mathrm{de}$ eeu van wesenlike belang. Nie alleen het hierdie ontwikkeling van die Aufklärung die geskiedenisbeeld van die Middeleeue en Reformasie met ' $n$ ander geskiedenisbeeld vervang nie, maar die letterlike betekenis van tekste en letters as Reformatoriese Skrifbeginsel het sy krag verloor. Verder is die aristotelies-ptolemeïese geosentriese wêreldbeeld deur Kopernikus en Galilei tot ' $n$ nuwe helio-sentriese wêreldbeeld begelei. Vir die Bybelwetenskappe en die Kerk was hierdie verandering ' $\mathrm{n}$ skok om te verwerk.

Die histories-kritiese omgang met Bybeltekste is die voorwaarde vir die teologiese verstaan daarvan (Zenger 19955:47). Dit dra daartoe by dat tekste in hulle groter samehange verstaan en beoordeel kan word. Hierdie breër kontekste sluit hulle literêre, sowel as hulle kanoniese samehange in.

Nuwe ontwikkelinge in die Bybelwetenskappe het noodwendig tot nuwe paradigmas en beklemtoninge in die verstaan van Bybeltekste aanleiding gegee. ' $n$ Kritiese benadering ten opsigte van bestaande paradigmas en hipoteses het hierdie prosesse versnel. Die laat datering van $\mathrm{Ou}-$ Testamentiese tekste deur verskeie eksegete, die bevraagtekening van die vroeë bestaan van "Bybelse" Israel deur sogenaamde "revisionist scholars" of minimaliste (Davies 1992; Lemche 1996; Thompson 1996; Whitelam 1996), verskeie nuwe argeologiese, epigrafiese en ikonogra- 
fiese ontdekkings2, die omdatering van die sogenaamde "Bondsboek" (Albertz 1994:78), asook nuwe hipoteses rondom die inbesitname van die land Kanaan (Gnuse 1997:346) is van die belangrikste beïnvloedende faktore wat die diskoers rondom die verstaan van die $\mathrm{Ou}$ Testament beïnvloed het.

Binne die mythos-debat van die Filosofie en Teologie het die tema van monoteïsme besondere belang verkry (Hossfeld 1985:57). Uit die debat blyk dit dat die verlies van die poli-mythie ten gunste van die mono-mythos asook die verbanning van die geskiedenis-veelvoud, dit wil sê die verstaan van die werklikheid deur middel van verskillende mites, nuwe teologiese nadenke noodsaak. Die kanonisering van ' $n$ enkele heilsgeskiedenis ("grand narrative") deur die Bybelse monoteïsme ten koste van meervoudige geskiedsbeskrywings plaas die Bybelse Teologie se verhouding tot Israel se Godsdiensgeskiedenis weer op die voorgrond. Godsdiens-historiese relasies tussen Bybelse tekste en hulle Nabye Oosterse Umwelt verdien opnuut aandag.

Dit is waar dat die Bybelwetenskappe in Suid-Afrika die Aufklärung van die 18de eeu grootliks gemis het (Le Roux 1994:199). Die historiese lees van tekste hier ter lande is baie swak ontwikkel. Vir die Ned Geref Kerk het die geskiedenis rondom J W Colenso (1814-1883) en J Du Plessis (1869-1935) gedurende die 19de en 20ste eeu die ontwikkeling van ' $\mathrm{n}$ historiese bewussyn verder gestrem. Dit bly egter die voortdurende opdrag van Bybelwetenskaplikes om, naas die beklemtoning van literêre perspektiewe, ook die verskillende historiese dimensies van Bybeltekste te beklemtoon. Die onderskeid tussen Bybelse geskiedenis en Israel se godsdiensgeskiedenis bly vir die meeste Bybellesers vreemd. Die wisselwerking tussen hierdie twee konsepte dra die sleutel tot ' $n$ beter Skrifverstaan.

\footnotetext{
2 Die argeologiese ontdekkings van Kuntillet 'Agrud (Kades: 850-837) en Kirbet el-Qôm (Hebron:750) met die seënwense daarop van "Jahwe ...en sy Ashera" het die monoteïsme-debat stimuleer. Die toename van kultiese praktyke rondom die godinfiguurtjies vanaf die tweede helfde van die 8ste eeu VGE het waarskynlik aanleiding tot profetiese kritiek daarteen gegee. Die Kuntillet 'Agrud - inskripsies, naamlik, "Jahwe uit Samaria" en "Jahwe uit Teman" bied ook interpretasiemoontlikhede van sogenaamde poli-jahwisme. Dit veronderstel verskillende vorme van Jahwe-aanbidding of Jahwe-vereringspraktyke. Die sentrale belydenis in Deuteronomium 6:4 ("Die Here is ons God, Hy is die enigste Here") het moontlik teen die agtergrond van sulke praktyke ontstaan (Höffken 1984:89). Ander argeologiese ontdekkings, soos die bulaltaar uit die hoogland van Samaria, of die 10de eeuse kultiese altaar Ta'anach onderstreep die vermoede dat aspekte van politeïstiese kultus-praktyke in die vroeë geskiedenis van Israel nie totaal verdwyn het of afwesig was nie.
} 


\section{SKRIFVERSTAAN MOET REKEN MET BEPAALDE IN- VALSHOEKE OP DIE TEKS}

Om Bybeltekste uit te lê en te verstaan, veronderstel bepaalde invalshoeke op die teks. Bybeltekste is literêr-gestolde en geïnterpreteerde geskiedsgebeure wat deur verskeie teologies geïnterpreteerde Schichten (tekslae) in verskillende kontekste tot selfstandige tekseenhede ontwikkel het. Om hierdie tekste vanuit 'n retrospektiewe blik te ontleed, kan eksegete in die lig van ontwikkelinge in die Bybelwetenskappe 'n verskeidenheid van benaderings aanwend (Human 1999:355).

Die vertrekpunte van hierdie benaderings kan opsommenderwys reduseer word tot die volgende (vgl Barton 1984:201): Eerstens stel eksegete vrae rondom die historiese gebeure of teologiese idees agter die teks. Daarby kom vrae rondom die outeur(s) deur wie die teks geskryf of die gemeenskap aan wie die teks(te) gerig is. Tweedens kom vrae aan die orde wat die literêre teks self raak en derdens word die teks ontleed met vrae wat die "bril" en konteks van die leser raak. Vanuit hierdie invalshoeke kan die vernaamste benaderings tot eksegese in ons tyd breedweg reduseer word tot die histories-kritiese benaderings, die vorm-analitiese benaderings en die resepsie-teoretiese benaderings tot teksanalise.

Die histories-kritiese metodes neem die historiese konteks of teologiese intensies agter die teks as vertrekpunt vir eksegese. Dit spreek verskillende diakroniese fasette aan om die ontstaan en ontwikkeling van ' $n$ teks te ontrafel. Tekortkominge aan hierdie metode, naamlik om alle vrae rondom die teks en sy struktuur te beantwoord, het stimulus aan vorm- en struktuur- oriënteerde benaderings verleen.

Vorm- of struktuuranalitiese metodes het aan die begin van die 20 ste eeu momentum begin kry. Met ' $n$ teksimmanente benadering wat ook as " $n$ "close reading" of literêre lees van die teks bekend staan, word sinkroniese aspekte van die teks ontleed. Die funksie van stylfigure asook die literêre vorm van die teks self dra tot die teologiese betekenis van die teks by.

Resepsie-teoretiese benaderings analiseer die teks vanuit die oogpunt van die leser of ontvanger in die kommunikasieproses. Met ' $\mathrm{n}$ onderskeid wat die eksegeet tussen die geïmpliseerde en werklike lesers van ' $\mathrm{n}$ teks maak, word die ontvanger se rol in die verstaansproses beklemtoon. Sy/haar voorveronderstellings asook die kontekstuele gesitueerdheid van die leser speel "n rol in hierdie leesproses. Die "bril" of konteks van die leser baan die weg vir byvoorbeeld die sosiologiese, psigologiese, ideologiese, politieke, feministiese, swart-teologiese of die bevrydings-teologiese lees van tekste. 
Die belang van sowel die historiese as literêre lees van Bybeltekste blyk dus ononderhandelbaar in ' $n$ komprehensiewe leesstrategie te wees (Human 1999:359ev). Die beoefening van dissiplines soos Tekskritiek, Literarkritiek, Vormkritiek, Oorleweringskritiek, Redaksiekritiek, asook Gattungs- en Tradisiekritiek dra by om die teks se gesitueerdheid, by name die Sitz(e) im Leben, Sitz in der Literatur en Sitz in der Liturgie vas te stel.

\section{HERMENEUTIESE UITDAGINGS VIR SKRIFVERSTAAN}

Vir baie mense is dit problematies en soms selfs godslasterlik om kritiese vrae aan die Bybel te stel. Ek respekteer hulle gevoelens en standpunte, maar daar moet nugterheid aan die dag gelê word om te weet dat Bybeltekste nie gelyk aan God is nie. Hierdie tekste getuig slegs van God. God is ook groter as die tekste of mense se kritiese refleksie daaroor. Die gevaar van bibliolatrie (aanbidding van die Bybel) moet nie die verwondering vir God self vervang nie. Ook die pous en konsilies van die Middeleeue of Hervormingstyd moet nie in ons tyd met ' $n$ papierpous, die Bybel, vervang of gelykgestel word nie.

Daar is egter verskillende probleme of uitdagings waarmee die Bybel-interpreteerder rekening moet hou by die wetenskaplike nadenke, uitleg en aktualisering van Bybeltekste. Die vernaamste daarvan sluit die volgende in:

\section{- Die Bybel is 'n produk van die antieke wêreld(e)}

Ou- en Nuwe Testament tekste is literêre produkte van die antieke wêrelde. Vandag se leser word direk gekonfronteer met die afstand en verskille van verskeie beskawings. Lessing se "garstige Grabe" is verstaanbaar wanneer ons vandag by die lees, toepassing en herformulering van Bybelinhoude raaksien dat die antieke beskawings ander wêreldbeelde, ander tydsbegrippe, ander verstaan van die geskiedenis, aardrykskunde, sterrebeelde of natuurstudies gehad het. Waarhede is met ' $n$ ander taal, ervaringswêreld en werklikheidbeskouing verpak as wat ons dit in ons eeu doen. Die wêreld wat op pilare gevestig was (1 Sam 2:8; Ps 104:5), is lank nie meer dieselfde as die wêreld van vandag met kernwapens, kloningsprojekte, selfone, Vigs, rekenaars en Challengerruimtereise nie. Dit is die uitdaging van die eksegeet om hierdie groot gapings in tyd, taal, kultuur, wêreldbeeld en geografie te oorbrug. Die Historiese Kritiek help ons daarmee sonder om geloof in God of die gesag van die Bybel prys te gee.

Binne hierdie konteks verdien die rol wat mythos in die antieke wêreld gespeel het, nadenke. Slegs by die aanhoor van die begrip "mite", assosieer baie moderne Bybellesers die begrip met fiksie, feëverhale of onwaarheid. Die Umwelt waarin Bybeltekste en verhale ontstaan het, 
was ryk aan mites. Mites is godeverhale wat ' $n$ kleurryke wêreld van meerdere gode en hulle interaksie veronderstel het (Bardtke 1989:941942). In wese is mites onhistories. Hierin word die aard van die mensewêreld op die godewêreld oorgedra. Met hierdie vertellinge wou die antieke mense die bo-natuurlike werklikheid en optrede van hul gode beskryf, verskynsels verklaar of die verloop van bepaalde gebeure beskryf (Sløk 1960:1263). So het hulle die waarheid binne hulle werklikheid tot uitdrukking gebring.

Binne die denkraamwerk van Israel was mites vreemd. Vir die monoteïstiese denke van die Jahwegeloof was mites eintlik wesensvyandig. Maar tog is daar spore van Nabye-Oosterse mites in Bybeltekste opgeneem. Ou Testament verhale deurasem die mitiese motiewe, raamwerke en spatsels van hulle Nabye Oosterse omgewing. In hierdie sin is die mythos in die monoteïstiese en historiese denke van Israel opgeneem. Mitiese motiewe en denke is binne die Jahwe-geloof gehistoriseer en het die funksie om die alleenmag van Jahwe in die hemel en op aarde te belig. Hiervan is daar talle voorbeelde in die $\mathrm{Ou}$ Testament3. Nuwe Testamentici sal vir ons geloofwaardig moet aantoon hoe hierdie verbande die Nuwe Testament raak en wat die funksie van sodanige motiewe is. Aspekte soos die geboorte en sterwe van ' $\mathrm{n}$ god, die maagdelike geboorte, opstanding (Wolmarans 2002: 63ev), Jesus wat op die wolke sal terugkeer, ensovoorts, noodsaak stylvolle beredenering wat lidmate se geloof in God rig, grond en bevestig (NGB Art. 5). My vraag: sou hierdie motiewe kon deel uitmaak van die Bybelse geloofstaal om God se alleenmag in die skepping deur die lewe en werk van Jesus Christus tot uitdrukking te bring, of nie?

Dit is duidelik dat die Bybel nie in isolasie van sy Nabye Oosterse en Mediterreense Umwelt gelees en bestudeer mag word nie. Die

3 Daar bestaan talle voorbeelde in hierdie verband: Jahwe is die alleen Skepper in plaas van ander gode (Gen 1); Jahwe vervang Assur en verplaas die songod Shamash as vestiger en onderhouer van wet en orde (Ps 72 - vgl Human 2002:658ev); Jahwe oorwin alle vyandelike chaosmagte, kry ' $n$ tempel en word as al-koning verklaar in plaas van Baal en Marduk (Eks 15); Jahwe beheer die skepping as ruiter van die wolke in plaas van Baal (Ps 104:3); Jahwe is Koning, Redder en Skepper in plaas van Jam of Baal (Pss 74:12-17; 89:7-11; Jes 51:9ev ). Ander mitiese motiewe is die chaos (Gen 1:2); die wêreldkoepel van God (Gen 1:2ev); aspekte van die Tuinverhaal (Gen 2:4b ev; Eseg 36:35); huwelik tussen gode-seuns en mense-dogters (Gen 6:1-4); chaos-stryd motief (Jes 17:1; 17:12ev; 30:7; 44:27; 50:2; 51:9); vrede tussen mens en dier in die Voortyd (Gen 1:29) wat weer in die Heils- of Eindtyd voorkom (Jes 11:1-9); die godeberg Sion, waarheen alle volke in Eindtyd terugkeer (Jes 2:2ev; Miga 4:1ev). Voorstellings van die hemel of hemelvergadering (Job 1-2; Ps 89:6-8; 113:5ev), die onderwêreld (Ps 139:8), die rol van die tempel as simbool van God se totale skeppingswerklikheid (Jes 6) asook die mitologiese funksie van geweld is ander voorbeelde wat raakpunte met Nabye-Oosterse voorstellings het. 
intertekstualiteit, diskussie en polemiek tussen Bybeltekste en die godsdiensliteratuur van sy tyd vereis ' $n$ breër leeswydte en studieveld.

\section{- Lang tydperke verloop tussen gebeure en die opskrifstelling daarvan}

Lang tydperke het soms verloop tussen gebeure wat in die Bybel beskryf word en die tyd wat dit neergeskryf is. Tussen hierdie twee punte het die proses van mondelinge tot skriftelike oorlewering en groei van tekste plaasgevind. Latere skrywers en redakteurs beskryf dus gebeure met ' $\mathrm{n}$ vooruitskouing, omdat hulle reeds weet wat in die geskiedenis gebeur het. Die boek Jesaja is ' $n$ goeie voorbeeld hiervan. Gebeure wat in die boek beskryf is, strek oor byna 3 eeue, vanaf die 8 ste tot die 5 de eeu VGE. Proto-Jesaja (1-39) vir die voor-ballingskapsgemeenskap, Deutero-Jesaja (40-55) vir die ballingskapsgemeenskap en Trito-Jesaja (56-66) vir die na-ballingskapsgemeenskap beskryf die verhouding van God met sy volk Israel oor ' $n$ lang tydperk. Hieruit is dit verder duidelik dat die profeet Jesaja nie alles in die boek geskryf het nie. Maar die betekenis en gesag van die boek kom nie daardeur in gedrang nie.

\section{- Meer as een wêreld is soms in 'n teks vasgevang}

In die ontstaans- en oorleweringsproses was tekste vir 'n aanvanklike situasie in die geskiedenis bedoel. Maar in volgende situasies is dit aangepas en nuut geïnterpreteer om weer nuwe kontekste en omstandighede aan te spreek. Soms is selfs byvoegings en veranderings aan die oorspronklike teks aangebring. Sodoende moet die Bybelleser by die verstaan van tekste daarmee rekening hou dat daar meer as een wêreld (konteks) in ' $n$ spesifieke teks vasgevang is. Die boek Hosea is ' $n$ voorbeeld. Die 8ste eeuse profeet het vir sy gemeenskap in die Noordryk gepreek. Na die val van Samaria (722) is sy oorlewerings en geskrifte na Juda/Jerusalem in die Suidryk geneem. Daar is dit aangepas by die omstandighede (3:5). Ook na die Babiloniese ballingskap is byvoegings tot die boek gemaak (14:10). Die eindproduk is die resultaat van 'n lang tydperk en oorleweringsproses. Die Bybelleser moet dit in ag neem.

\section{- Bybelse gebruike en gewoontes is vandag onbekend}

Sommige gebruike, gewoontes en praktyke uit Bybelse tye is vir die hedendaagse mens onbekend en onverstaanbaar. Die ruil van ' $n$ sandaal by die lossingsprosedure (Rut 4:6ev), seremoniële wassing (Mark 7:3ev), die hoofbedekking (1 Kor 11:4), 'n koei se as in reinigingswater (Num 19 ) is enkele voorbeelde. Die godsdienstige, sosiale en kulturele agtergrond van die Nabye Ooste en Mediterreense gebiede moet hierby verreken word. Antieke en moderne gebruike, sosiale strukture of gedragspatrone kan nie heen en weer en oor eeue oor verskillende kulture uitgeruil word nie. Liturgiese danse of reinigingsgebruike is 
vandag in baie kulture nie meer deel van godsdienshandelinge by die aanbiddingsplek nie. Die funksie daarvan kan bepaal word en vandag op kultureel-eie manier tot uitdrukking kom. Wie liturgiese danse in die gemeente wil doen, is dus nie meer "Bybels" gehoorsaam as ander wat dit nie doen nie. Dit geld vir talle ander sake.

\section{- Daar is by ons ' $n$ gebrek aan geografiese besonderhede}

' $n$ Gebrek aan geografiese kennis en oriëntasie tot die verskillende Bybellande verhinder mense soms om die Bybel beter te verstaan. Talle Bybelse plekke bestaan vandag nie meer nie. Selfs met die hulp van argeologiese en epigrafiese materiaal is dit moeilik om plekke en gebeure histories te lokaliseer.

Argeologiese ontdekkings dra as hulpwetenskap by om die Bybel beter te verstaan. Maar met argeologie kan Bybelse gebeure nie bewys of rekonstrueer word nie. Klippe, potskerwe en strukture van klei kan nie praat nie. Dit moet deur die argeoloog of Bybelwetenskaplike interpreteer word. Nuwe argeologiese ontdekkings bevraagteken vandag ook talle bestaande teorieë. Dit stel die Bybelwetenskappe voor nuwe uitdagings.

\section{- Taalgrense verhinder begrip vir spesifieke woordinhoude}

Taal skep grense. Hebreeus, Aramees en Grieks is vir die gewone lidmaat ontoeganklik. Verskillende soorte vertalings maak dit egter makliker vir mense om die Bybel beter te verstaan. Idiome, metafore, taalkonstruksies, kennis van die antieke kulture asook wêreldbeskouings van destyds is nodig om die tekste te dekodeer en te vertaal. Selfs die mees gesoute vertalers het nie " $n$ greep op baie Bybelse begrippe nie.

Kritiese nadenke laat vrae ontstaan of die begrippe waarmee ons vandag Bybelterme vertaal, dieselfde semantiese inhoud dra as wat antieke mense daaronder verstaan het. So kom begrippe soos die vir kerk, ampte, huwelik, homoseksualiteit (Botha 2002:18-51), geregtigheid, en talle ander onvertaalbare begrippe onder die vergrootglas.

\section{- Teenstrydighede/diskrepansies in die Bybel}

Gemeet aan die hedendaagse geskiedenis- en waarheidsbeskouing bevat die Bybel talle historiese teenstrydighede. Enkele hiervan sluit die volgende in: Wat het tydens Israel se deurtog by die Rietsee gebeur? Het Moses die water met ' $\mathrm{n}$ stok geslaan (Eks 14:16)? Het Moses sy hande oor die water uitgesteek (Eks 14:21), of het God net die water aangespreek (Ps 106:9)? Het Jesus opgevaar na die hemel vanaf Galilea (Matt 28:16) of vanaf Betanië (Luk 24:52)? Het Judas, Jesus se verraaier, 
homself opgehang (Matt 27:5), of het hy vooroor geval en oopgebars (Hand 1:18)? Het die Here Dawid aangehits om die volk te tel (2 Sam 24), of het Satan dit gedoen (1 Kron 21)? Het farao (Gen 12) of Abimelek (Gen 20) die aartsmoeder Sarai as vrou begeer, of wou Abimelek Isak se vrou, Rebekka vat (Gen 26)?

Omdat ons weet dat die $\mathrm{Ou}$ Testamentiese wêreld met ' $\mathrm{n}$ ander geskiedenis- en waarheidsbegrip werk as wat sedert die moderne tyd heers, help die Historiese kritiek ons om hierdie teenstrydighede te verstaan sonder dat dit die waarhede in die verhaal of gesag van die teks aantas. Ons hoef hierdie teenstrydighede nie te ontken, weg te redeneer of te harmoniseer nie. ' $n$ Verdere troos wat hieruit voortvloei, is dat geloofsekerhede nie in historiese feitelikhede nie, maar in teologiese waarhede gegrond is.

Die Bybel is nie ' $\mathrm{n}$ geskiedenisboek of wetenskapshandleiding in die moderne positivistiese of post-moderne sin van die woord nie. Met die onderskeid tussen Bybelse Geskiedenis (in die teks) en die Godsdiensgeskiedenis van Israel (agter die teks) verstaan ons dat geskiedenisfeite vir Bybelskrywers nie onbelangrik was nie. Maar historiese feitelikheid was ondergeskik aan die teologiese intensie van Bybelskrywers en redakteurs. Historiese feite is gekleur met ' $n$ teologiese interpretasiekleed. Feite kon dus selfs "verkeerd" aangebied word sonder om die waarheid van die verhaal aan te tas.

\section{- $\quad$ Bybellesers het verskillende voorveronderstellings}

Elke Bybelleser interpreteer die Bybel met 'n eie "bril". Daarom kan niemand die Bybel objektief lees nie. Voorwetenskaplike kennis van die lewe, die wêreld en bepaalde lewensbegrippe kleur mense se verstaan van Bybeltekste. Voorkennis en voorveronderstellings en voorwetenskaplike kennis (Bosman 1986:8) is inherent deel van die mens. Dit word bepaal deur die leser se opvoeding, kultuur, sosio-ekonomiese agtergrond, siening van die kerk, denominasie, godsdiens en politiek.

Hierdie voorkennis en voorveronderstellings is nie verkeerd nie. Maar die leser moet in die interpretasieproses met sy eie voorverstaan van tekste gekonfronteer word. Dit geskied alleenlik deur kritiese vrae aan die teks te stel. By die onkritiese omgang met Bybeltekste bestaan die gevaar dat die tekste slegs ' $n$ spieël vir die leser se eie voorstellings, wense en vooroordele word, in plaas daarvan dat die leser met hom/ haarself gekonfronteer word ten einde insig in hom/haarself, die wêreld en sy/haar God moontlik te maak (Zenger 19955:46).

\section{- $\quad$ Erken die kommunikasieproses}

Een van die opvallendste maniere waarop die Bybel soos ' $n$ toorboek funksioneer, is wanneer mense tekste en verse lees en toepas asof dit 
direk aan die moderne mense gerig is. Sonder inagneming van teksgedeeltes se breër literêre en kanoniese kontekste word inhoude op vandag toegepas. Probleemloos en konteksloos word tekste gebuig om vroom en godsdienstige bedoelings ter wille te wees. Dit mag nie.

Bybeltekste is nie direk aan die moderne leser gerig nie. Nee, vandag se leser is ' $n$ indirekte hoorder van die teks. Paulus skryf aan die gemeentes van Romeine of Korinthe, terwyl Jesaja of Miga aan die geloofsgemeenskap van Juda/Jerusalem skryf. Hierdie skrywers rig hulle met bepaalde teologiese oogmerke deur middel van 'n kommunikasiemedium, ' $n$ brief of dokument, aan bepaalde gemeenskappe wat geloofsworstelinge of probleme ervaar. Soos toeskouers op " $n$ pawiljoen is die hedendaagse mense indirek by die kommunikasieproses betrokke. Daarom moet die leser eers uitmaak wat die konteks, problematiek en moontlike oplossings van Bybelse geskrifte is, voordat hulle inhoude kan aktualiseer of toepas.

\section{- Verskillende literatuursoorte vra 'n gedifferensieerde lees}

Die Bybel bevat verskillende literatuursoorte. Die geboorte van die moderne literatuurwetenskap in die 20ste eeu beklemtoon dit meer as ooit tevore dat die Bybelse biblioteek verskillende literêre genres bevat, wat elkeen volgens die reëls en konvensies van taal gelees moet word. Die beeldspraak, stylfigure en metriese eenhede van poësie word anders interpreteer as ' $\mathrm{n}$ verhaal/vertelling wat met karakters, tyd, ruimte, intrige, ' $n$ spanningslyn en skrywersperspektief verhaalwaarhede wil konstrueer.

Onder hierdie breë genre-kategorisering bestaan daar nog talle ander moontlikhede: Die Bybel bevat nog liedere, briewe, geslagsregisters, profetiese uitsprake, wysheidspreuke, leerdigte, apokaliptiese materiaal, gelykenisse, voorgeskiedenis, wette, kronieke ens. Elkeen druk die waarheid op ' $\mathrm{n}$ ander manier uit. Al hierdie genres word nie op een manier uitgelê nie. Daarom vra dit kennis van die leser om literatuursoorte gedifferensieerd te lees.

\section{VEELHEID VAN PERSPEKTIEWE}

Die opkoms van die histories-kritiese wetenskappe asook die ontwaking van die moderne literatuurwetenskappe het tot ' $n$ veelheid van teologiese perspektiewe aanleiding gegee. Dit het die gevolg dat tradisionele teologiese temas of kategorieë, soos byvoorbeeld God, mens, wêreld, skepping, verlossing, lyding, sonde, Jesus, Gees, ensovoorts, nie meer so uniform en eenduidig gekategoriseer kan word nie. Daar bestaan nie net een 'prentjie' van ' $\mathrm{n}$ saak nie. Vir elke tema is daar verskillende, en soms teenstrydige perspektiewe. Hierdie situasie plaas die dogmatiese wetenskappe en Sistematiese Teologie in ' $n$ onbenydenswaardige dilemma. 
Om die veelheid van eksegetiese navorsingsresultate en teologiese moontlikhede, wat nie eers binne die Bybelwetenskappe genoegsaam verreken is nie, te sistematiseer, is ' $n$ onbegonne taak.

' $n$ Belangrike gevolg wat uit die veelheid van eksegetiese perspektiewe vloei, is dat mense hierdie veelkleurige resultate soms as aanval op die gesag en waarheid van die Bybel of op God beskou. Die oorleweringskritiek help ons om te besef dat God in die geskiedenis op baie maniere met, in en deur mense of sy skepping gewerk het. Soos daar by die beskrywing van ' $n$ motorongeluk verskillende verhaalvariante moontlik is, geld dieselfde beginsel by Skrifverstaan. Die gesag van Bybeltekste en die waarhede wat dit beskryf, word nie deur 'n veelheid van perspektiewe op ' $n$ saak opgehef nie.

\section{ROL VAN DIE NUWE HERVORMING - 'N EIE EVALU- ERING}

Ek beskou die sogenaamde Nuwe Hervorming binne Suid Afrika as ' $n$ protesbeweging teen verstarde praktyke oor Skrifverstaan en die onbeweeglikheid van tradisionele kerke om geloofswaarhede in eietydse idiome tot uitdrukking te bring. Lede van die beweging is gefrustreerd omdat insigte van die Bybelwetenskappe nie vinnig en diepgaande genoeg tot hulle reg kom binne die kerklike gemeenskappe nie. Craffert4 meen die doel is "om ' $n$ alternatief te bied vir diegene wat 'n probleem ondervind met die ortodokse verwoording van die Christelike geloof".. "'n alternatiewe diskoers vir diegene wat hulle nie met die ortodokse verwoording kan vereenselwig nie".

Om die Christelike geloof in eietydse taal en idiome te verwoord is opsigself ' $n$ reformatoriese beginsel. Daarmee kan nie veel fout gevind word nie. Anders verstaan ek nie wat gereformeerd of reformatories is nie. My aanvoeling is dat die gesprek om verskeie redes ietwat ontspoor. Ek noem enkele sake kursories:

- Die debat vind nie in ' $n$ veilige gespreksruimte plaas nie. Die radikaliteit waarmee voor- en teenstanders van die beweging mekaar pak oor uiters sensitiewe geloofsake soos Jesus, die opstanding, maagdelike geboorte ens veroorsaak dat niemand mekaar voluit aanhoor nie. Dit skep 'n onpastorale gesindheid tussen deelnemers wat nie die debat dien nie.

- Vanuit 'n akademiese en wetenskaplike oogpunt kom die geloofwaardigheid van die gesprek in gedrang omdat vakspesialiste hulle uitlaat oor spesialiteitsprobleme van ander vakterreine. Ou Testa-

4 Craffert (2002:87). Wolmarans (2002:65) meen nuwe insigte moet help om "nuut na die vorm van ons godsdiens te kyk". 
mentici, Praktiese Teoloë, Sistematies Teoloë, joernaliste en ander wetenskaplikes spreek hulle met gesag oor spesialiteitsaspekte van die Nuwe Testament uit. Natuurlik mag almal aan die gesprek deelneem, maar vakspesialiste moet die problematiek van die debat blootlê en pastoraal begelei.

- Ad hominem en styllose persoonlike aanvalle van gespreksgenote op mekaar plaas die niveau van die debat op 'n lae vlak. Dan reflekteer elke reaksie die indruk dat elke deelnemer sy eie persoon en belange beskerm.

- Verskeie leidinggewende gespreksgenote van die Nuwe Hervorming reflekteer ' $\mathrm{n}$ nä̈witeit oor die godsdiensbelewing van die deursnee kerklidmaat. Hulle veronderstel dat baie mense hulle godsdiens rasioneel beleef, terwyl dit nie die geval is nie. Daarmee saam vertaal hulle die resultate van hulle teologiese insigte nie in emosionele en pastorale geloofstaal nie.

- Die geslotenheid waarmee die beweging hom aanbied, skep die indruk van ' $n$ bevrydingsbeweging wat buite kerk(e) opereer. As hierdie beweging hul insigte met kerklidmate wil deel, sal gesprekke in en met kerke veel meer simpatiek moet plaasvind.

- Die indruk bestaan dat Nuwe Hervormers die naelstring met die teologiese tradisie wil deursny sonder om plaasvervangende inhoude in die plek van hul kritiek te gee. Meestal konfronteer hulle mense met die eindresultate van hul langverwerfde teologiese insigte, terwyl hulle verwag dat lidmate en ander gelowiges sonder dielang-pad-van-groei nuwe teologiese insigte moet aanvaar.

- Die naam Nuwe Hervorming kan misleidend wees. Binne die breë konteks van die Bybelwetenskappe is die meeste insigte van hierdie beweging die produk van denke wat reeds hulle oorsprong in die Aufklärung van die 18de - 20ste eeu het. Die vraag is: Ten opsigte waarvan is hierdie hervorming nuut. Dit het nie die pastorale intensie van die 16de eeuse Hervorming nie, maar reflekteer veeleerder intellektuele doelwitte. Die beweging funksisioneer lokaal binne die Suid-Afrikaanse konteks, terwyl hulle reikwydte nie die universele dimensie van die 16de eeuse beweging weerspieël nie.

\section{PASTORALE SLOTOPMERKING}

Dit pas by die aard van die gereformeerde tradisie om die Christelike geloof vir elke tyd en konteks relevant en nuut te formuleer. Daarom moet mense in die Kerk voortdurend nuut dink oor hulle geloof, omdat die wêreld waarin hulle leef snel verander. Om krities oor God, die Bybel en geloof te dink, is nie " $n$ teken van ongeloof of beteken nie die afbreek van die Bybel se gesag nie. Dis eerder ' $n$ proses om tot selfinsig 
te kom, nuwe perspektiewe oor God te ontdek en die onwikkelingsproses van die Bybel beter te verstaan. "n Kultuur van debatvoering binne en buite die Kerk moet hieroor voortdurend geskep en stimuleer word. Mag ook hierdie debat vir lidmate en gelowiges tot ryke insigte oor hulleself, die Bybel en God lei.

\section{Literatuurverwysings}

Albertz, R 1994. "Der Ort des Monotheismus in der israelitischen Religionsgeschichte". In: Dietrich, W \& Klopfenstein, M (Hrsg). Ein Gott allein? JHWH-Verehrung und biblischer Monotheismus im Kontext der israelischen und altorientalischer Religionsgeschichte (13. Kolloquium der Schweizerischen Akademie der Geistes-und Sozialwissenschaften 1993 - OBO 139). Freiburg, Schweiz: Universitäts-Verlag, 77-96.

Bardtke, H 19896. "Mythen", in: Gutbrod, K, Kücklich, R \& Schlatter, T (Hrsg). Calwer Bibellexikon. Stuttgart: Calwer Verlag, 941-942.

Barton, J 1984. Reading the Old Testament. Method in biblical study. London: Darton, Longman \& Todd.

Bosman, H L 1986. "Die ontstaan en verstaan van die Ou Testament", in: Deist, F E, Vorster, W S e a (reds). Woorde wat ver kom. Die literatuur van die Ou Testament. Kaapstad: Tafelberg, 1-15.

Botha, P J J 2002. "Die drange van hulle hart... (Rom 1:24-27)". Verbum et Ecclesia 23(1), 18-51.

Craffert, P F 2002. "Die Nuwe Hervorming: wat waaroor, waarheen?", in: Muller, P (red), Die Nuwe Hervorming. Pretoria: Protea Boekhuis, 67-87.

Davies, P R 1992. In search of “Ancient Israel” (JSOT). Sheffield: Sheffield Press.

Gnuse, R K 1997. No other Gods. Emergent monotheism in Israel (JSOT Suppl 241). Sheffield: Sheffield Academic Press.

Hossfeld, F L 1985. "Einheit und Einzigkeit Gottes im frühen Jahwismus", in: Böhnke, M \& Heinz, H (Hrsg). Im Gespräch mit dem dreieinigen Gott. Elemente einer trinitarischen Theologie. Festschrift für W Breuning. Düsseldorf: Patmos.

Höffken, P 1984. Eine Bemerkung zum religionsgeschichtlichen Hintergrund von Dtr 6,4”, Biblische Zeitschrift 28, 88-93.

Human, D J 1999. "Die literêr-historiese lees van 'n teks”, Skrif en Kerk 20(2), 354-368.

-, 2002. "An ideal for leadership - Psalm 72: The wise king - Royal mediation of God's universal reign", Verbum et Ecclesia 23(3), 658-677.

Lemche, N P 1996. "Early Israel revised". Currents in Research: Biblical Studies 4, 936.

Le Roux, J H 1994. "Historical criticism - The end of the road?". Old Testament Essays 7(4), 198-202.

Muller, P (red) 2002. Die Nuwe Hervorming, Pretoria: Protea Boekhuis.

Sløk, J 1960. "Mythos und Mythologie", in: Van Campenhausen, H F, Dinkler, E ua (Hrsg). Die Religion in Geschichte und Gegenwart3, Handwörterbuch für Theo- 
logie und Religionswissenschaft, Tübingen: Mohr (Siebeck), 1263-1268.

Spangenberg, I J J 1998. Perspektiewe op die Bybel. God se woord in mensetaal, Pretoria: Van Schaik.

-, 2002. "Die Bybel en die Nuwe Hervorming", in: Muller, P (red). Die Nuwe Hervorming, Pretoria: Protea Boekhuis, 88-111.

Thompson, T L 1996. "Historiography of Ancient Palestine and early Jewish Historiography: W G Dever and the Not So New Biblical Archaeology”, in: Fritz, V \& Davies, P R (Ed). The origin of the Ancient Israelite States, 26-43.

Van der Toorn, K 1999. "God (1)" in: Van der Toorn K, Becking B, \& Van der Horst P W (Eds). Dictionary of Deities and Demons in the Bible. Leiden: Brill, 352-36.

Whitelam, K W 1996. The invention of Ancient Israel: The silencing of Palestinian History, London: Routledge.

Wolmarans, H 2002. "Die Nuwe Hervorming", in: Muller, P (red). Die Nuwe Hervorming. Pretoria: Protea Boekhuis, 63-66.

Zenger, E 19955. Das erste Testament. Die Jüdische Bibel und die Christen, Düsseldorf: Patmos. 